Southern Illinois University Carbondale

OpenSIUC

7-2009

\title{
Watershed Retrofit and Management Evaluation for Urban Stormwater Management Systems in North Carolina
}

Kathy DeBusk

Bill Hunt

Upton Hatch

Olha Sydorovych

Follow this and additional works at: http://opensiuc.lib.siu.edu/ucowrconfs_2009 Abstracts of presentations given in Session 2 of the 2009 UCOWR conference

\section{Recommended Citation}

DeBusk, Kathy; Hunt, Bill; Hatch, Upton; and Sydorovych, Olha, "Watershed Retrofit and Management Evaluation for Urban Stormwater Management Systems in North Carolina" (2009). 2009. Paper 8.

http://opensiuc.lib.siu.edu/ucowrconfs_2009/8 


\title{
Watershed Retrofit and Management Evaluation for Urban Stormwater Management Systems in North Carolina Miss Kathy DeBusk, Dr. Bill Hunt, Dr. Upton Hatch, Dr. Olha Sydorovych
}

\begin{abstract}
In response to water quality concerns in the Jordan Lake Reservoir and state and federal mandates, several cities in North Carolina are being required for the first time to reduce nutrient loads in stormwater from previously developed lands; that is, install retrofits. It is anticipated that similar requirements will become necessary for other urban areas as North Carolina. The goal of this study is to evaluate the feasibility of alternative approaches to stormwater management for existing developments within North Carolina cities. Evaluated alternatives include retrofitting onsite best management practices, off-stream treatment along mainstems of the urban drainage network, stream restoration, and alteration of stream corridors as urban greenways, among others. Geographic coverage of the study includes seven cities of the WRRI Urban Water Consortium Stormwater Group. Stormwater drainage networks at the citywide/watershed scale will be related to existing land use, land use plans, and zoning classes. Feasibility of alternatives will be measured by the cost-effectiveness of alternative practices in reducing peak flows and pollutant loads (nutrients and sediment) and the potential for ecological restoration. Two spatial scales will be used for feasibility analysis: One will focus on tributary watersheds at a scale of 260-520 hectares (1-2 $\left.\mathrm{mi}^{2}\right)$, and one watershed from each of the cities will be selected with priority given to watersheds draining to impaired water bodies. The feasibility of retrofitting onsite BMPs within these watersheds will be evaluated. The second scale will focus on mainstems of drainage networks in one selected watershed to determine the feasibility of using larger off-stream management practices and improving stream corridor management.
\end{abstract}

\section{Introduction}

In 2005, North Carolina was the $5^{\text {th }}$ fastest growing state in the country, with populations increasing by $1.7 \%$ between July 2004 and July 2005 and by $7.9 \%$ between 2000 and 2005 (US Census Bureau). Furthermore, the number of people living in the state in 2000 is projected to increase by approximately 33\% by the year 2010 (US Census Bureau). An increase in population leads to an increase in development and infrastructure, which is directly related to the quality of surface waters draining these areas. Increases in runoff volume and velocities, coupled with the substantial amount of land disturbance required by construction, greatly increases the amount of sediment introduced to surface water bodies via erosion and channel incision (Colosimo and Wilcock 2007; Meyer 2005). In addition, numerous studies have demonstrated elevated concentrations of nutrients, such as nitrogen and phosphorus, as well as other substances such as chlorine, sulfate, and ammonium in streams draining urban areas (Biggs et al. 2004; Wheeler et al. 2005; Phillips and Bode 2004).

North Carolina is a unique state in that the barrier islands lining the coast have lead to the formation of the second largest estuary system in the United States, which drains seven of the North Carolina's 17 watersheds. Estuaries are complex and fragile ecosystems, are home to a large variety of aquatic life and support the shellfish and seafood markets that are important to North Carolina's economy. Increases in urbanization throughout North Carolina and surrounding areas have led to water quality degradation in the estuaries due to increased nutrient and sediment concentrations. Excess nutrients have caused eutrophication and low oxygen levels, as 
well as stimulated Pfiesteria piscicida, the combination of which led to major fish kills in the 1990s. The fish kills were viewed as a threat to human health and to NC's economy and prompted immediate action to address the declining quality of rivers and estuaries within the state. Strict laws and regulations were put into place to govern the quality and quantity of stormwater leaving newly developed or redeveloped sites.

While these regulations have been successful in improving water quality within the state, the ever-increasing amount of urbanization and its threat to water quality have led regulators to require, in some areas, the implementation of retrofit stormwater treatment practices for existing development. It is anticipated that this requirement will become mandatory for many urban areas across the state of North Carolina. As such, it is important to understand the feasibility, both physically and economically, of implementing such practices.

\section{Project Description and Goals}

The goal of this project is to evaluate the feasibility and cost-effectiveness of treating stormwater in urban areas that have already been developed. Analyses were/will be conducted in two parts (some tasks have already been performed, while others are on-going). For the first part, seven North Carolina cities that are members of the Urban Water Consortium Stormwater Group served as the study locations: Raleigh, Durham, Greensboro, Wilmington, High Point, WinstonSalem and Charlotte. Each city was asked to submit three tributary watersheds ranging from 260 to 520 ha and one watershed from each city was selected for analysis. Preference was given to watersheds draining to an impaired stream. Additionally, the watersheds selected for each city were chosen such that together the eight selected watersheds represented a variety of development densities ranging from rural to ultra-urban. Potential retrofit opportunities were not considered when selecting these watersheds.

GIS information such as topographic, hydrologic, parcel and land use data were compiled for each watershed and, using this information, potential best management practice (BMP) retrofit locations were identified. BMPs to be considered included: "regulation" size standard structural practices (bioretention, wet ponds, stormwater wetlands, sand filters), under- and oversized practices (for sites where the retrofit practice would be either too small or too large for the contributing drainage area), off-line large, regional facilities (stormwater wetlands, wet ponds), innovative structural practices (green roofs, cisterns, level spreader/filter strip combinations, permeable pavement) and non structural practices (street-sweeping). Each watershed was visited to ground-truth the GIS data, analyze the feasibility, contributing drainage area, estimated size and specific location for each potential retrofit BMP. These site visits were also used to characterize the watershed and neighborhoods and identify potential retrofit locations that were not identified via GIS analyses.

A comprehensive list of potential retrofit practices was compiled for each of the eight watersheds. The contributing drainage area size was estimated for each potential BMP and the required BMP size were determined. A literature review will be conducted to determine representative pollutant loadings for each land use type and removal rates that can be expected for various pollutants for each BMP type. Pollutants to be considered include sediment, nitrogen and phosphorus. Using the collected data and representative loadings and removals, annual pollutant loadings entering each BMP and annual pollutant removal loads will be estimated for each BMP. Hydrologic performance of each BMP will also be considered by estimating the amount of water entering each practice and using a research-determined, representative value of volume reduction for the BMP type. 
An estimated cost and economic feasibility will be determined for each BMP. Consideration will be given to tradeoffs among initial investment cost, annual maintenance cost and functional life of the BMP. Net present value calculations will be used to provide an estimate of the relative values of alternative BMPs, and the pollutant removal benefit associated with each BMP will also be determined. For selected parameters with benefits and costs that are difficult to quantify, a sensitivity analysis will be used within the expected values. Results will be presented to each participating city, with retrofit opportunities assigned to one of two tiers. The first tier represents the most cost-effective retrofit opportunities within the watershed, while the second tier represents those BMPs that would provide a more marginal pollutant removal return on the investment.

Part 2 of this project will analyze a larger watershed, approximately 2,000-2,500 ha, that encompasses one of the smaller watersheds discussed previously. Analyses for this watershed will determine the viability of using large, off-stream management practices as well as urban stream corridor management techniques. Feasibility will be measured by the cost-effectiveness of alternative practices in peak reducing peak flows, removing pollutant and the potential for ecological restoration. This paper focuses on Part 1 of the project.

\section{Watershed Characteristics \& Analyses}

Seven of the eight eligible cities became study participants. One tributary watershed was chosen for each of the seven watersheds; an eighth watershed was chosen from the remaining watersheds. This watershed was chosen so that as many levels of development were represented as possible among the eight study locations. The eighth selection was a watershed in the city of Greensboro; therefore, Greensboro had two watersheds to be analyzed. The land use composition of each of the eight watersheds is shown in Figure 1. Of the eight watersheds, five have been analyzed for potential retrofit BMPs and visited for ground-truthing. These five will be the basis for discussion for the remainder of this paper.

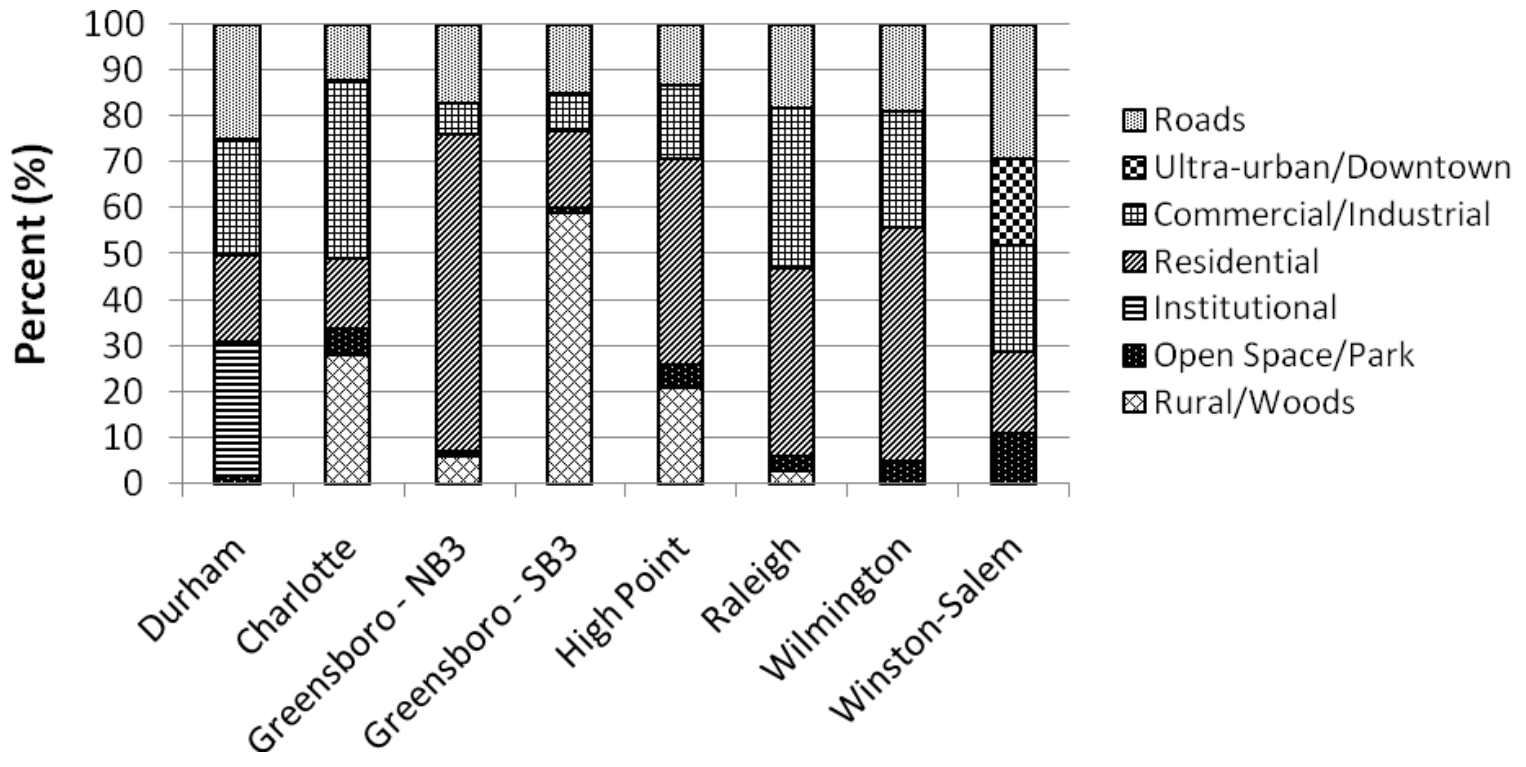

Figure 1. Land use composition of the eight tributary watersheds chosen for analysis. 


\section{Durham}

The tributary watershed selected for the City of Durham is approximately 190ha and drains to New Hope Creek, which is located within the Cape Fear River Basin. New Hope Creek was listed on the 2006 North Carolina 303-d impaired streams list due to fecal coliform bacteria, turbidity, low dissolved oxygen and biological integrity (NCDENR 2007).

As indicated by Figure 1, the land use within the watershed is split fairly evenly among roads (25\%), commercial/industrial (25\%), residential (19\%) and institutional (29\%). Figure 2 shows the distribution of different land uses throughout the watershed. The category 'institutional' refers to the Duke University campus, which is concentrated in the northwest part of the watershed. Parcels tagged as residential are grouped together in three major sections with commercial/industrial areas scattered throughout. Roads and right-of-ways represent a significant portion of the watershed, but offer little opportunity for retrofitting due to utilities, lack of space and cost. New Hope Creek is piped through much of the watershed and only daylights in a few locations, the longest section being 66m (216 l.f.), which eliminates the opportunity for large, off-line systems.

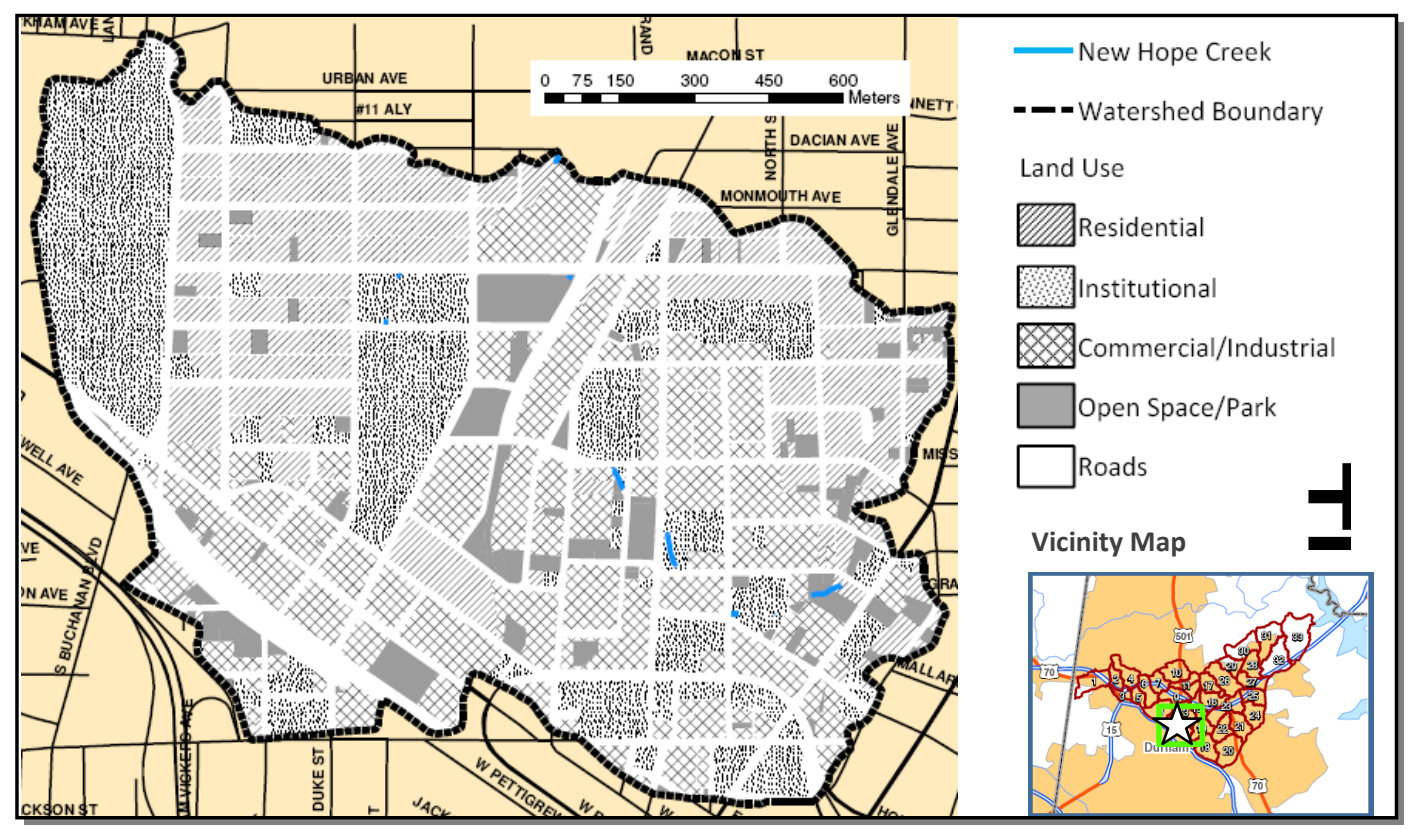

Figure 2. Land use map for the New Hope Creek watershed in the City of Durham, NC (City of Durham, 2009).

As shown in Table 1, the most abundant type of retrofit opportunity identified was permeable pavement, which includes the replacement of existing impermeable parking lots. As Durham is located within the piedmont region of North Carolina and has soils with significant clay content, permeable pavement applications must include underdrain systems which increases the cost of the retrofit considerably. Bioretention retrofit BMPs were preferred in older, less used areas, as opposed to permeable pavement, due to the high costs associated with pervious pavement applications. Bioretention areas would also provide more water quality improvement and peak flow reduction than permeable pavement. The most common applications of bioretention retrofits in the Durham area included parking lots and commercial/industrial land uses. Institutional areas tend to be most suited for incorporating water harvesting BMPs 
(cisterns) and/or bioretention. Water harvested from rooftops can be used for irrigating open spaces and lawns. Residential areas offer an environment that is quite difficult for retrofitting. While large retrofit BMPs are typically not feasible in these areas due to parcel size and private ownerships, city-sponsored programs offering cost-share options for converting paved driveways to permeable pavement or the installation of rain gardens could be very successful and offer significant improvements in stormwater quantity and quality.

Table 1. Potential BMP retrofits identified for each watershed via GIS analyses and watershed visits.

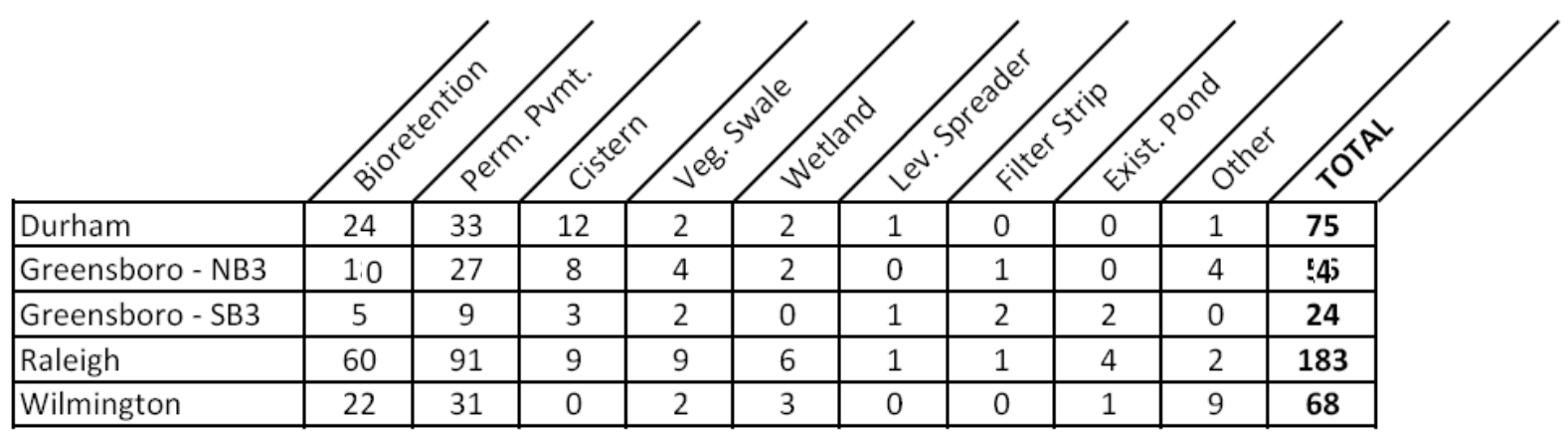

\section{Greensboro - NB3}

One of the two watersheds selected within the City of Greensboro drains to North Buffalo Creek and is approximately 290 ha in size (Figure 3). North Buffalo Creek is located within the Cape Fear River Basin and is impaired due to fecal coliform (NCDENR 2007).

This watershed is predominantly residential (69\%) with only a small portion of commercial/industrial land use $(7 \%)$. The portions of the watershed used for commercial/industrial uses proved to be ideal for permeable pavement applications; hence, the large number of permeable pavement BMPs identified as potential retrofits. The majority of the potential bioretention BMPs were also identified in commercial/industrial areas. The residential portions of the watershed were divided into separate neighborhoods based on house type, age of neighborhood and lot size. Each neighborhood was then visited and characterized as to which type of BMPs would, in general, be most appropriate and applicable. For example, relatively new, up-scale neighborhoods where the majority of driveways were paved were noted as candidates for permeable pavement initiatives. Older neighborhoods with semi-permeable gravel driveways might be more suitable for programs or initiatives that encourage the installation of backyard rain gardens. The general upkeep and presentation of the houses and lots in each neighborhood was noted to get an idea of how receptive citizens would be to incorporating BMPs into their yards. This survey allowed for an estimate of what percentage of the neighborhood could potentially be retrofitted if involved in a rigorous incentive program sponsored by state or local agencies.

\section{Greensboro - SB3}

The second of the two watersheds located within Greensboro is approximately 303 ha and drains to South Buffalo Creek. South Buffalo Creek is located within the Cape Fear River Basin and is listed on North Carolina's 303-d list due to biological integrity/turbidity (NCDENR 2007).

At approximately $60 \% \mathrm{rural} /$ woods, this watershed represents the rural/undeveloped end of the land use spectrum (Figure 4). As shown in Table 1, there were much fewer potential 
retrofits identified in this watershed than in watersheds with more development. This was predominantly due to the fact that existing rural and agriculture land uses, by nature, offered stormwater quantity and quality control. Most large tracts of agricultural/rural land drained to a pond which acted like a retention pond. Houses were located on large parcels and impervious areas drained to grassed or wooded areas where water was allowed to infiltrate. Roads were lined with grassed swales, as opposed to curb and gutter, and drained to grassed or wooded areas. In general, rural land within this watershed was very efficient in reducing and treating stormwater and left little room for improvement by means of retrofit BMPs. Residential areas in the watershed were analyzed using the same procedure as described for watershed NB3. There were

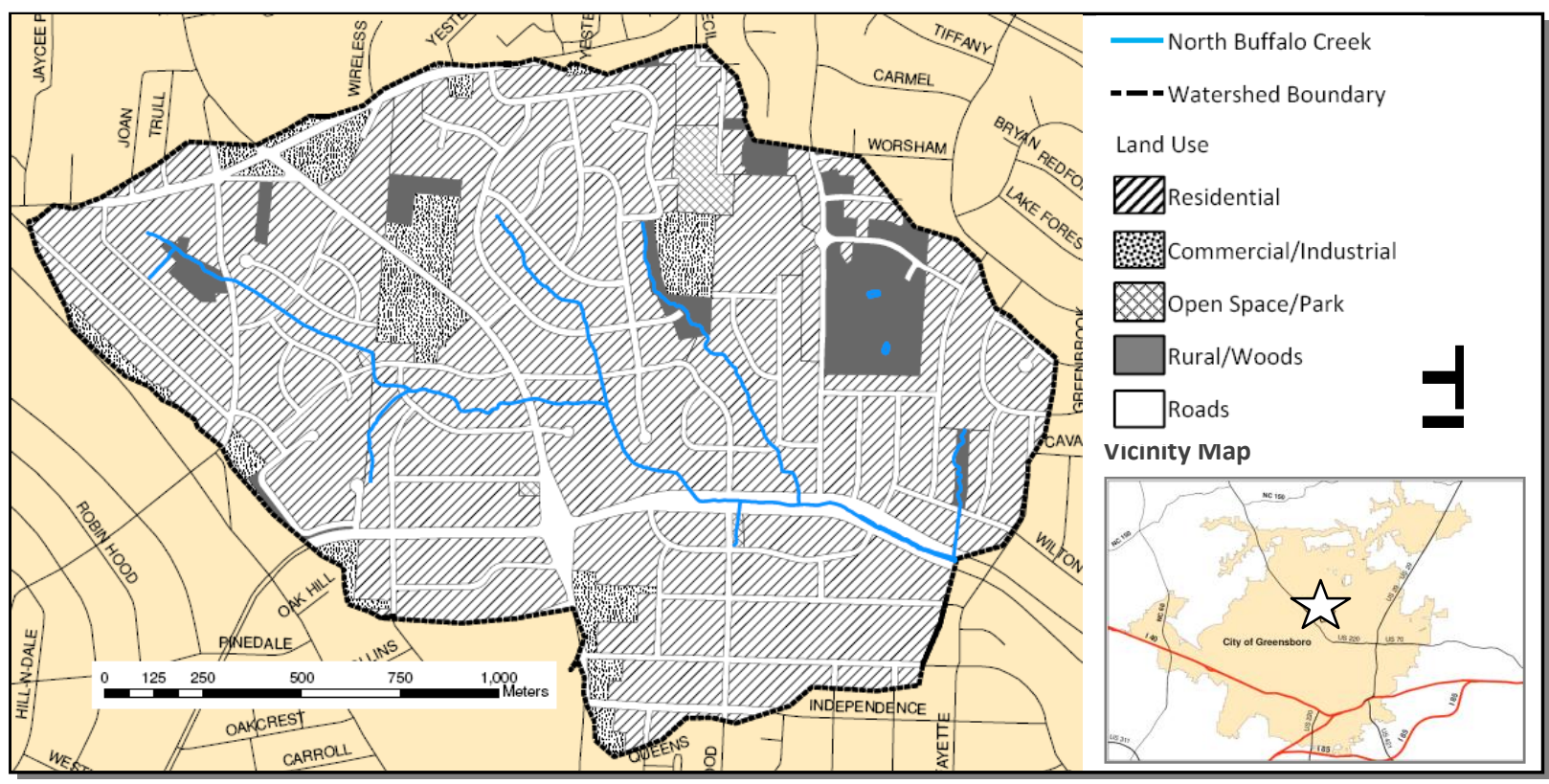

Figure 3. Land use map for the North Buffalo Creek watershed in the City of Greensboro, NC.

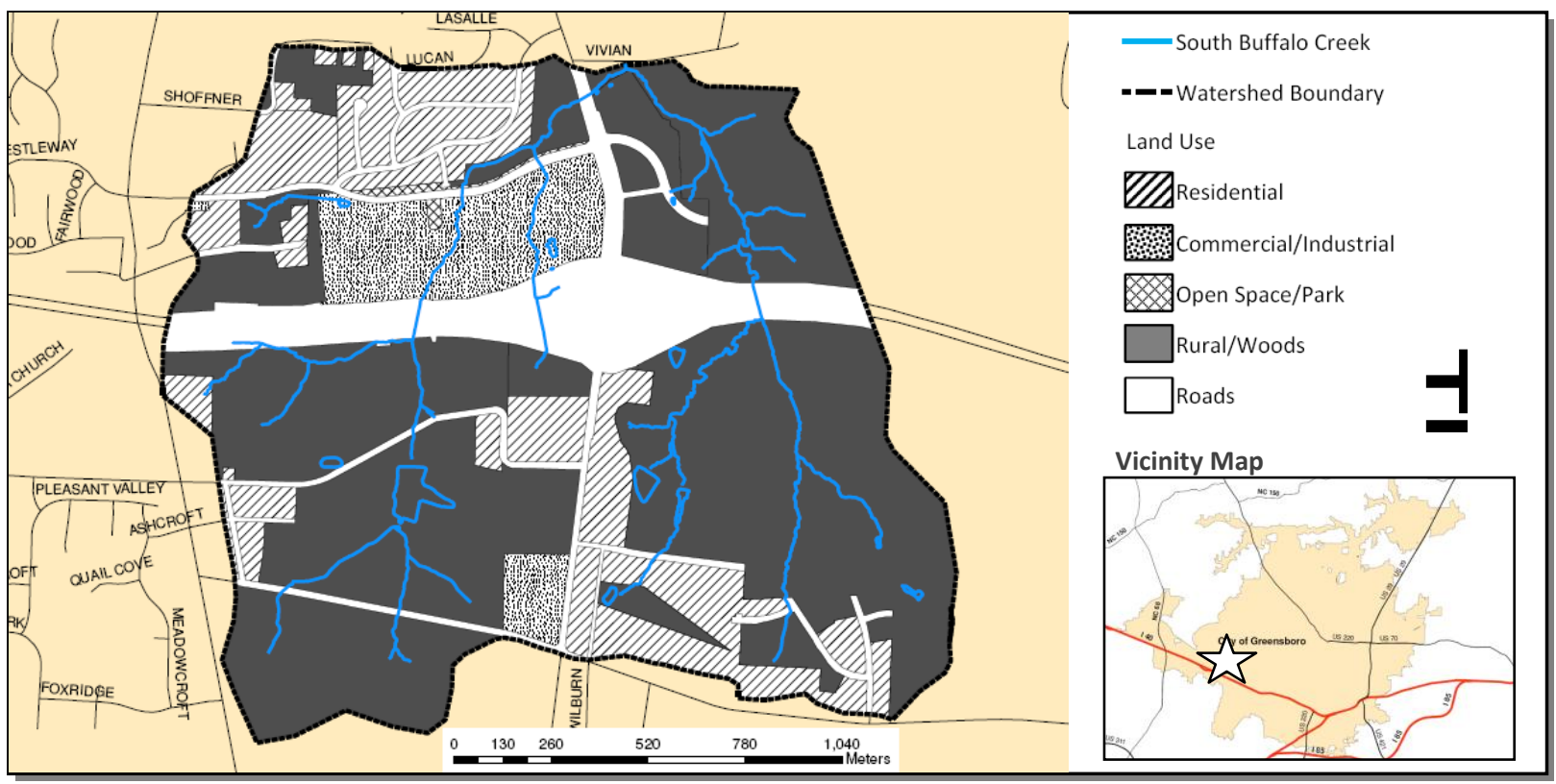

Figure 4. Land use map for the South Buffalo Creek watershed in the City of Greensboro, NC. 
two areas identified as commercial/industrial land use and both offered opportunities for retrofitting parking lots with permeable pavement. The larger of the two areas, shown in Figure 4, was a large shopping mall that was treated by two retention ponds. These retention ponds could be improved by either incorporating wetland features or adding aquatic benches to increase uptake of pollutants. Interstate 40 runs through this watershed but slope and accessibility issues did not allow for treatment of the runoff by retrofit BMPs.

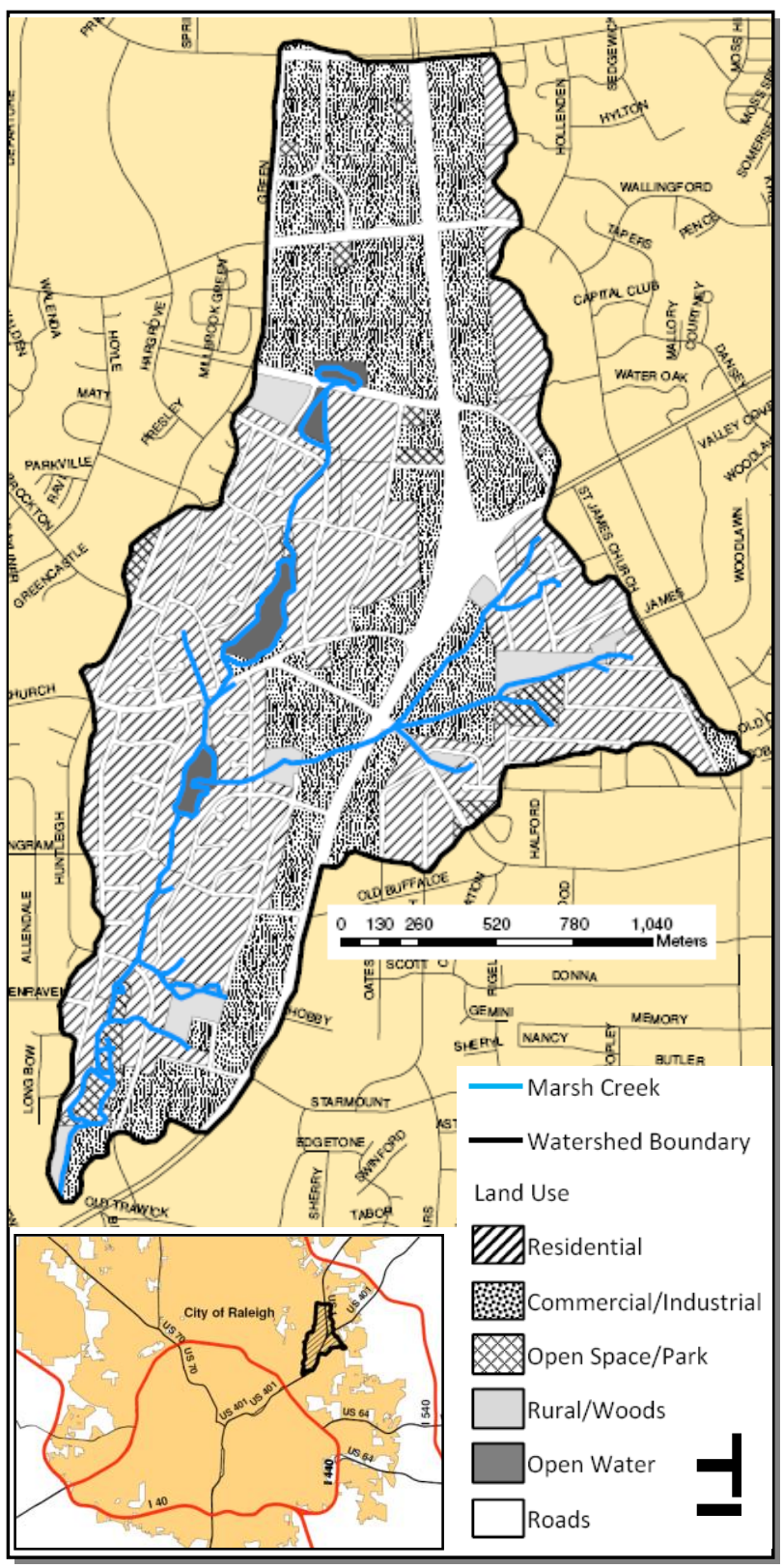

Figure 5. Land use map for the Marsh Creek watershed in the City of Raleigh, NC.

\section{Raleigh}

The watershed selected for the City of Raleigh is 394 ha and drains to Marsh Creek, a tributary of the Neuse River. Marsh Creek is impaired due to biological integrity (NCDENR 2007).

The Marsh Creek watershed (Figure 5) encompasses a large section of commercial development that runs alongside Capital Boulevard (US 1); however, several residential areas are also included within its boundaries. As shown in Table 1, this watershed had a large number of retrofit opportunities. The majority of the commercial/industrial areas were well suited for permeable pavement and/or bioretention practices. The residential portions of the watershed were assessed using the procedure described previously, and four existing retention ponds could undergo improvements to increase the uptake of pollutants and nutrients. Two locations were identified as ideal for creating large stormwater wetlands and each has the potential to drain a significant amount of land, a combined total of approximately 35 ha. One of these locations was an existing retention pond while the other is currently a wooded section surrounded by commercial development. These large-scale BMPs are ideal retrofits, as they treat a large amount of land and are situated on a single parcel of land. Overall, this watershed provided excellent opportunities for retrofit practices. 


\section{Wilmington}

The Downey Branch watershed in the City of Wilmington is approximately 135 ha and is located within the Cape Fear River Basin. Listed on North Carolina's 303-d list, Downey Branch is impaired due to biological integrity and sediment (NCDENR 2007).

The Downey Branch watershed, as shown in Table 1 and Figure 6, is predominantly residential $(51 \%)$ with some commercial/industrial uses $(25 \%)$. The residential areas offered few opportunities for retrofits, as the soil is very sandy and water from rooftops and driveways infiltrates into the surrounding lawns areas rather quickly. The commercial areas were well suited for the implementation of bioretention and permeable pavement practices due to sandy soils and flat terrain. Several of the streets within the watershed were bordered by wide rights-ofway and provided excellent opportunities for street-side BMPs, also known as street-edge alternatives (SEA) (SPU 2009). Street-side BMPs, noted as "Other" in Table 1, could include linear bioretention, grassed swales or infiltration trenches. One large-scale BMP was identified within this watershed and involved the conversion of an existing retention pond to a stormwater wetland system. This system could potentially drain a significant portion, approximately 13.5 ha, of the commercial areas located in the southwestern part of the watershed.

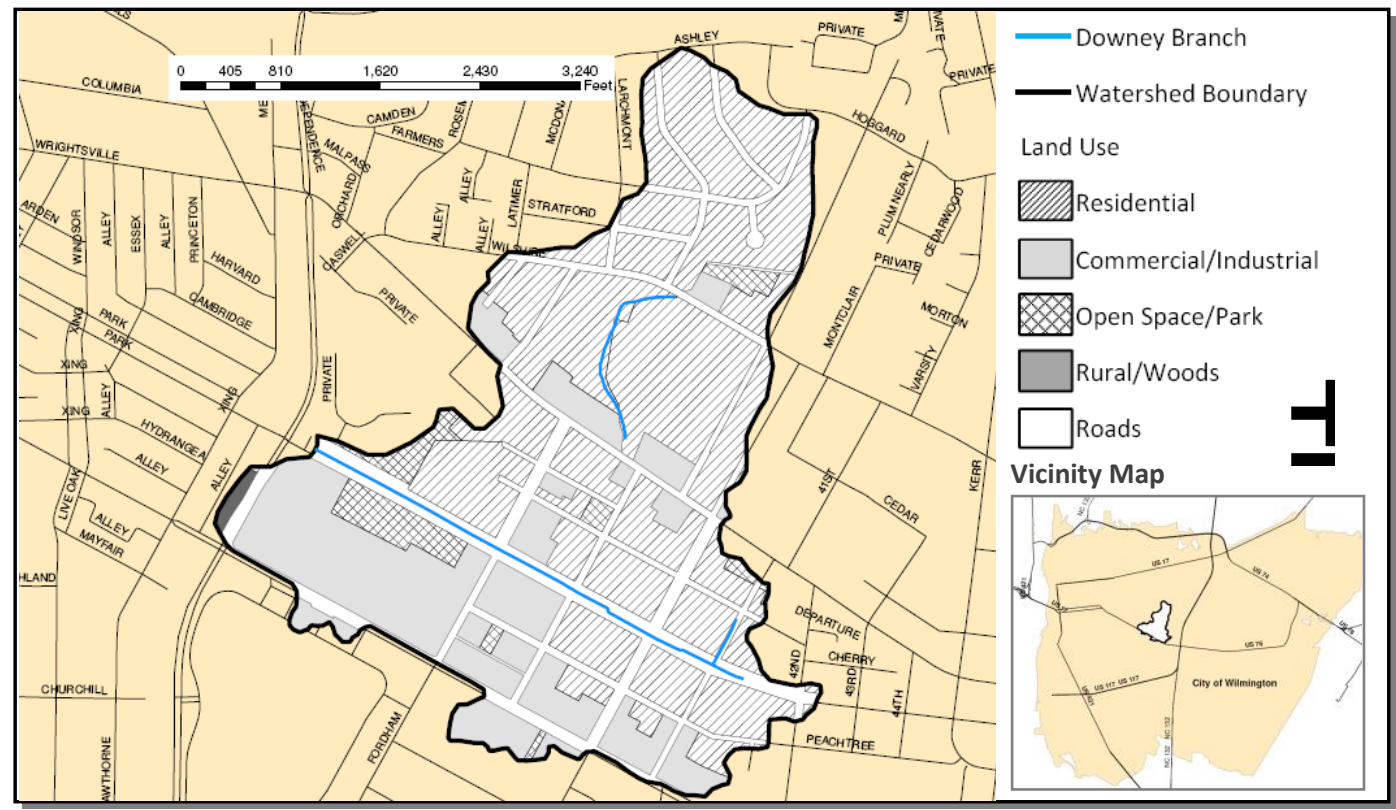

Figure 6. Land use map for the Downey Branch watershed in the City of Wilmington, $\mathrm{NC}$.

\section{Trends and Conclusions}

The analyses of these five watersheds revealed several relationships between the type of land use and the most applicable retrofit BMPs. Note that these trends are general conclusions drawn from the five watersheds previously discussed and may not be necessarily representative of any single watershed.

\section{Commercial/Industrial}

There tends to be a large number of retrofit opportunities in commercial and industrial areas. Permeable pavement and bioretention cells are the most common choice for retrofit BMPs, as 


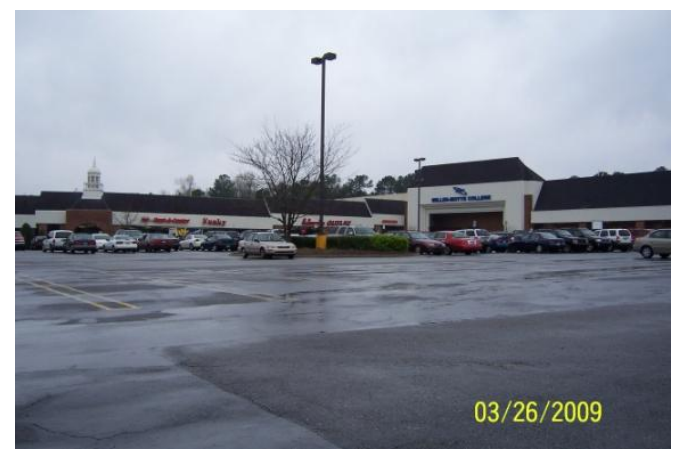

Figure 7. Example of a typical commercial development in Raleigh, NC. they can be fitted into a typical commercial site rather well. Watersheds with sandy soils have a greater economic advantage because BMPs would not require an underdrain system, which greatly decreases the cost of implementation. Sites with little to no slope are ideal for permeable pavement, as steep slopes decrease the functionality of the system and cost more to construct. Steeper slopes are treated best with bioretention. Additionally, bioretention cells are preferred over permeable pavement for parking lots that are dilapidated. This is due to the high potential for lack of maintenance and upkeep, as well as the higher costs associated permeable pavement systems. Figure 7 shows a typical shopping mall site in

the Raleigh-Marsh Creek watershed. At this site, it was suggested that permeable pavement be considered for the stalls in the parking lot. Additionally, median strips located at the bottom of the slope (to the left of the picture) could be converted to bioretention strips. In some areas entire developments drain to one stormwater retention pond. Converting these ponds to wetlands, or incorporating wetland features, could improve their pollutant removal capabilities.

\section{Residential}

Developing a blanket statement as to which retrofit BMPs are most suitable for residential land uses is quite problematic, as the type of neighborhood has a significant impact on which BMPs would be most likely accepted and applicable. Newly built townhomes and houses on small lots (0.1-0.2 ha) are extremely hard to retrofit, as there is very little pervious area in which a BMP can be placed. Figure $8 \mathrm{a}$ is an example of such a neighborhood. Large houses, wide concrete driveways, wide streets with curb and gutter and small lawns generate a large amount of runoff, but leave very little room to incorporate retrofit BMPs. Houses on large lots (0.3-0.5 ha) located within older neighborhoods have large lawns that may be used to incorporate BMPs, as shown in Figure 8b.

In residential areas, the general affluence of the neighborhood is a factor that must be considered when evaluating what types of BMPs would be most suitable. Upper class neighborhoods tend to have paved driveways, while middle and lower class neighborhoods often have gravel driveways. A neighborhood where the majority of driveways are paved would be an ideal candidate for a rigorous, but expensive, permeable pavement incentive program. Older middle-class neighborhoods would be more suited to a rain garden implementation incentive program. Figure $8 \mathrm{c}$ is an example of a middle- to upper-class neighborhood that would benefit from permeable pavement and rain garden incentive programs. The majority of residents in lower-income neighborhoods may be discouraged by construction costs and maintenance requirements of retrofit BMPs and therefore would probably not be good candidates for BMP implementation programs.

An evaluation of the appearance of properties within a neighborhood can offer good indications as to the general acceptance of retrofit BMPs. Houses with elaborate and well-kept flowerbeds were considered to be more likely to embrace the implementation of a rain garden. Homes where the lawns are sparse and rarely mowed would probably not be willing to properly maintain a retrofit BMP. Other indicators of general BMP acceptance include the presence of 


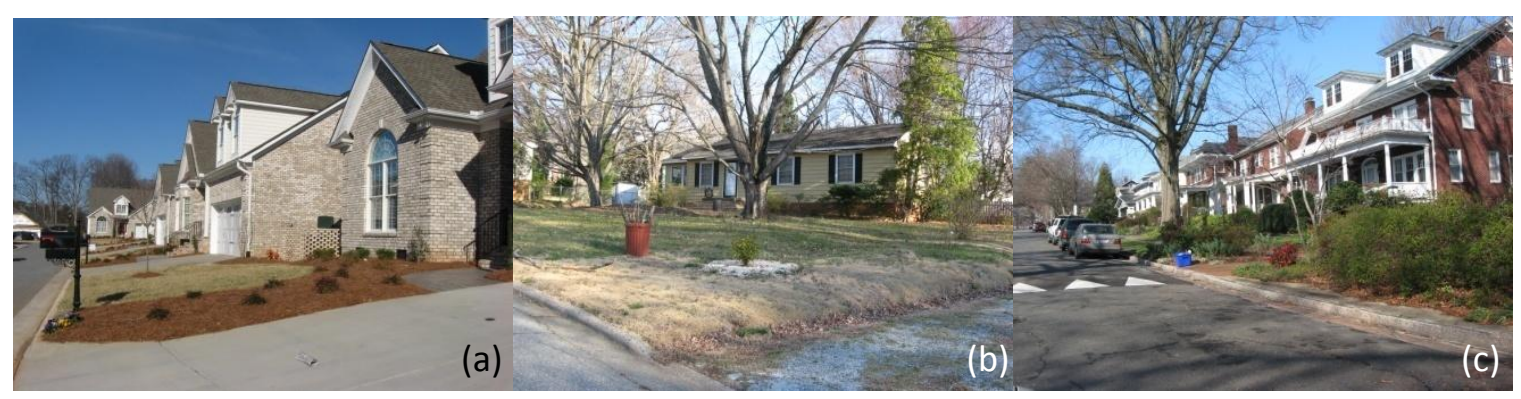

Figure 8. (a) A new townhome community located in the Greensboro NB3 watershed. (b) A house on a large lot in an older neighborhood in the Greensboro NB3 watershed. (c) Houses located on small lots in an older neighborhood within the Durham-New Hope Creek watershed.

rain barrels or cisterns, recycling bins and yard art or landscape features. When evaluating a neighborhood, the percentage of homes that would embrace a BMP retrofit program was estimated. For example, it was estimated that 1 of 4 homes (25\%) in a middle-class Greensboro neighborhood would be willing to implement retrofit BMPs as part of an incentive program.

\section{Institutional}

Land belonging to a university (example shown in Figure 9) provides unique opportunities for BMP retrofits due to the university's attention to maintenance, commitment to environmental stewardship and the potential of integrating research opportunities and funds with a retrofit project. The most efficient BMP for this type of environment may be the collection of rooftop runoff to be used for irrigation purposes. The large number of buildings, as well as the accessibility to open space, lawn and flower beds makes this a preferable practice when compared to other retrofit options. Bioretention is also a practice that fits in well at an institutional location. These retrofit BMPs can mitigate stormwater while functioning as additional flowerbeds or landscape features.

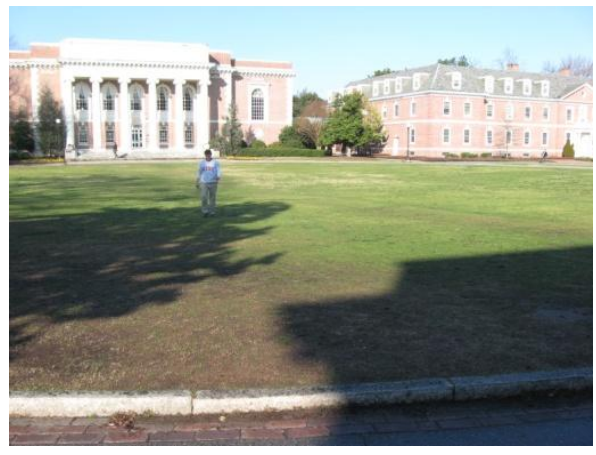

Figure 9. The campus of Duke University located the Durham-New Hope Creek watershed.

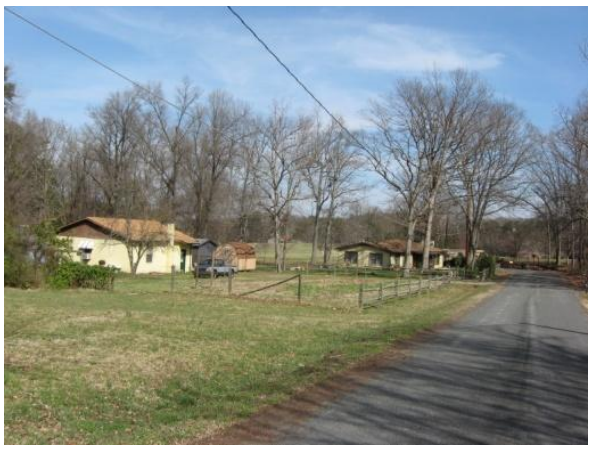

\section{Rural/Woods}

As discussed in the Greensboro SB3 watershed section, rural land offers little in the way of the retrofit opportunities. An example of this type of land use is shown in Figure 10. No urban BMP retrofits are needed in these areas to obtain good water quality.

\section{Open Space/Park}

Land functioning as open space or a park can sometimes

Figure 10. A home located in a rural be a good location for large-scale BMPs if there is a area of the Greensboro SB3 watershed. significant amount of land draining to it. However, grassed areas provide excellent treatment in terms of 
allowing infiltration and filtering sediment from runoff. Therefore, in these areas it is rare that retrofit BMPs would be cost- effective. Also, care must taken to ensure that open space areas are not intended for other land uses before designating them for retrofit BMPs.

\section{Future Analyses}

This project is in its very early stages and much work remains. The last three watersheds located in the City of Charlotte, the City of High Point and the City of Winston-Salem will be analyzed and ground-truthed similarly to the five presented in this paper. Once these visits and analyses are complete, a thorough evaluation of each proposed retrofit BMP will be conducted and each BMP will be rated according to its physical and economical feasibility, taking into account design constraints, potential water quality improvement and total cost, among other things. This evaluation will be performed for each watershed and the results will be put together in a report and presented to the city.

As described in the 'project goals and description' section, a larger watershed will be selected and analyzed for off-stream management practices and urban stream corridor management techniques as part 2 of the project. A full physical and economical feasibility study will be conducted for this watershed and results will be presented to the city in which it is located.

\section{References}

U.S. Census Bureau. www.census.gov. Accessed 1 April 2009.

Biggs, T. W., T. Dunne, and L. A. Martinelli. 2004. Natural controls and human impacts on stream nutrient concentrations in a deforested region of the Brazilian Amazon basin. Biogeochemistry. 68: 227-257.

Colosimo, M. F., and P. R. Wilcock. 2007. Alluvial sedimentation and erosion in an urbanizing watershed, Gwynn Falls, Maryland. Journal of the American Water Resources Association. 43 (2): 499-521.

Meyer, S. C. 2005. Analysis of base flow trends in urban streams, northeastern Illinois, USA. Hydrogeology Journal. 13: 871-885.

NCDENR. 2007. North Carolina 2006 303-d List. Raleigh, NC: North Carolina Department of Environmental and Natural Resources. <http://h2o.enr.state.nc.us/tmdl/documents/303d_Report.pdf >

Phillips, P. J., and R. W. Bode. 2004. Pesticides in surface water runoff in southeastern New York State, USA: Seasonal and stormflow effects on concentrations. Pest Management Science. 60: 531-543.

SPU. 2009. Street edge alternatives (SEA streets) project. Seattle, WA: Seattle Public Utilities. Available at: http://www.seattle.gov/util/About_SPU/Drainage_\&_Sewer_System/Natural_Drainage_S ystems/Street_Edge_Alternatives/index.asp. Accessed 29 April 2009.

Wheeler, A. P., P. L. Angermeier, and A. E. Rosenberger. 2005. Impacts of new highways and subsequent landscape urbanization on stream habitat and biota. Reviews in Fisheries Science. 13: 141-164. 


\section{Author contact information:}

Kathy M. DeBusk, EIT

Extension Associate

NC State University

Biological and Agricultural Engineering

Campus Box 7625

Raleigh, NC 27695

(919) 515-8595

kathy_debusk@ncsu.edu

William F. Hunt, PE, PhD

Associate Professor

NC State University

Biological and Agricultural Engineering

Campus Box 7625

Raleigh, NC 27695

(919) 515-6751

wfhunt@ncsu.edu

Upton Hatch, $\mathrm{PhD}$

Acting Director, NC WRRI

NC State University

Box 7912

Flex Bldg, Module 7

1575 Varsity Dr

Raleigh, NC 27695

(919) 513-1145

luhatch@gw.fis.ncsu.edu

Olha Sydorovych, PhD

Researcher

NC State University

Agricultural and Resource Economics

Box 8109

Raleigh, NC 27695

(919) 513-0185

obsydoro@ncsu.edu 